\title{
Cutting the Network, Knotting the Line: a Linaeological Approach to Network Analysis
}

\author{
Gísli Pálsson ${ }^{1}$ \\ Published online: 18 April 2020 \\ (C) The Author(s) 2020
}

\begin{abstract}
Network methods have seen a rapid rise in archaeology in recent years. There are still concerns regarding how well formal networks are able to effectively model local interaction. These are often present in the so-called qualitative network approaches - studies that tend to be based on close readings of relations between entities and the way they form dynamic networks of agents. Such studies have demonstrated the value in scrutinizing the way in which relations might be acted on in practice, and how that might differ from expected results. But rarely do such studies produce network data of the kind analyzed by formal network analytical methods. Formal approaches, on the other hand, blur the specificity of individual relations and trade much of their specificity for the ability to make general statements about relations across large datasets. More generally, the modality of the relation/edge is a crucial way in which formal network analysis differs from other prevalent relational approaches popular in archaeology today, where the substantivity of individual relations is paramount. Such relations are often seen as starting points for subsequent hybridizations that radically alter, if only temporarily, the structure of their respective networks. I argue that a key step in allowing networks to reformulate from initial, datadriven network schemata is the introduction of a more symmetrical agency between the node and the edge. In this article, I discuss how ethnographic sources can be used to achieve this for archaeological survey data. I use assemblage theory as a framework to explore the potential the edge has to offer archaeological network modelling. While assemblage theory is helpful for this purpose, the lack of a computational formality to assemblage theory immediately places it at odds with network science. As a complement, I will also employ the computational ontology CIDOC-CRM to more explicitly articulate the character of links between nodes in archaeological networks. The paper will end by suggesting a method of network modelling which integrates the line as a key source of agency. As a nod to Ingold's call for an increased emphasis on the line, I call this approach network linaeology.
\end{abstract}

Keywords Assemblage theory $\cdot$ CIDOC-CRM $\cdot$ Network analysis $\cdot$ Iceland $\cdot$ Eighteenth century $\cdot$ Historical archaeology

Gísli Pálsson

gisli.palsson@gmail.com

Extended author information available on the last page of the article 
Nothing can hold on unless it puts out a line, and unless that line can tangle with others.

Tim Ingold, Life of Lines, p. 3.

Network methods have seen a rapid rise in archaeology in recent years. As Brughmans and Peeples (2017) point out, more archaeological network studies have been published in the past 5 years than in the previous 50 . This proliferation of research has shown that network approaches have both strengths and weaknesses for articulating archaeological data. There are still concerns regarding how well formal networks are able to effectively model local interaction (see Knappett 2011, pp. 30-41). These are often present in the so-called qualitative network approaches - studies that tend to be based on close readings of relations between entities and the way they form dynamic networks of agents (e.g. Latour 2005). Such studies have demonstrated the value in scrutinizing the way in which relations might be acted on in practice, and how that might differ from expected results. But rarely do such studies produce network data of the kind analyzed by formal network analytical methods. Formal approaches, on the other hand, blur the specificity of individual relations and trade much of their specificity for the ability to make general statements about relations across large datasets.

This blurring sets formal network analysis in contrast to other prevalent relational approaches popular in archaeology today, where the substantivity of individual relations is paramount. Such relations are often seen as starting points for subsequent hybridizations that radically alter, if only temporarily, the structure of their respective networks. This notion can be found in Latour's hybrids (2005), Strathern's dividuals (1990), Hodder's entanglements (2012) and Ingold's meshworks (2011), to name a few examples.

This paper is neither a critique of formal network analysis nor of qualitative approaches, but a suggestion of how to bring the two perspectives closer by considering how one might incorporate more substantive characterizations of edges in network models. I argue that a key step in allowing networks to reformulate from initial, datadriven network schemata is the introduction of a more symmetrical agency between the node and the edge. In this article, I discuss how ethnographic sources can be used to achieve this for archaeological survey data. I use assemblage theory (DeLanda 2006, 2016) as a framework to explore the potential the edge has to offer archaeological network modelling. While assemblage theory is helpful for this purpose, the lack of a computational formality to assemblage theory immediately places it at odds with network science. As a complement, I will also employ the computational ontology CIDOC-CRM to more explicitly articulate the character of links between nodes in archaeological networks. The paper will end by suggesting a method of network modelling which integrates the line as a key source of agency. As a nod to Ingold's (2015) call for an increased emphasis on the line, I call this approach network linaeology.1

\footnotetext{
${ }^{1}$ Note that I will not use Ingoldian metaphysics at all; I am only using his neologism linaeology.
} 


\section{Network Analysis: Context and Introduction}

While the term network is commonplace in archaeological writing, formal network analysis (FNA) refers to specific techniques (see Brughmans 2010). In short, FNA introduces constraints on data types and relationships that allow for generalized analyses of networks using a host of methods. A typical formal network will only have two types of data - the node and the edge. However, nodes can have many modes. A unimodal network is populated with nodes that are all comprised of the same kind of data - a network of authors, excavators and social media users. Multimodal networks are more complex, modelling the relationships between a heterogeneous set of actors.

The use of network analysis in archaeology is well documented, and currently, it is more helpful to summarize recent reviews than to repeat them. Reviews of network principles and applications in archaeology from the early 2010s by Brughmans (2010, 2013) and Knappett $(2005,2011,2013)$ show that network ideas had been present in archaeology for decades, but at the time had not yet made a major impact on the discipline. The work by these two authors (and others, e.g. Mills et al. 2013) became highly influential, however, and helped catalyze what has been a steady increase in network approaches to archaeology over the last decade. Archaeological network analysis has also clearly matured since the early 2010s, when Brughmans (2013, pp. 653-654) noted a lack of understanding of the potential of network analysis in archaeology. This is perhaps best borne out by recent edited volumes and special issues (Brughmans et al. 2016; Collar et al. 2015; Evans and Felder 2014; Knappett 2013, 2014) and reviews of specific issues in archaeological network analysis, such as social network analysis (Mills 2017) and the processes of network modelling (Amati et al. 2018). More recently, Peeples (2019) expanded on a bibliographic review by Brughmans and Peeples (2017) to provide a comprehensive overview of the current state of formal network approaches in archaeology.

\section{The Shrinking Space Between Quantitative and Qualitative Networks}

Archaeological network analysis has come far since the beginning of the decade, when there was very limited dialogue between archaeologists doing FNA and those using network concepts in different forms (see Knappett 2011, pp. 30-41). Since then, several studies have narrowed the gap. Knappett (forthcoming) has discussed the implications of the so-called Strathernograms for formal network modelling. These graphs are Gell's interpretation of Strathern's work (Gell 1999; Strathern 1996) to model social interaction that takes place in networks at the micro-scale. He problematizes nodes in networks by using Strathern's (1990) concept of the dividual, a relational concept of the person as made up of the various relations in which he or she participates. As Strathern explains (and Gell illustrates), a pig exchange in Melanesian culture ${ }^{2}$ when a person gives a pig to another person, they are not simply exchanging an alienable product, but are also giving away part of themselves. As Knappett points out, this initial exchange is relatively simple to model in network terms, but quickly becomes more complicated as the pig can then be exchanged again, leading to further divisions of the dividuals

\footnotetext{
${ }^{2}$ More specifically, the way Strathern interprets Melanesian culture in her research.
} 
involved in the historical chain of exchanges. In other words, as persons in a Melanesian social network begin to exchange pigs, the network retains the memory of every exchange through the dispersal of identity into dividual assemblages representing a person or pig, and traces of every exchange he or she has participated in. In a sense, the nodes themselves develop into sub-nodal networks, which become embedded into the network with every exchange in a continuous internal growth of network structure. Knappett refers to this as a 'Melanesian ontology of face-to-face networks', although he does not attempt to build a computational schema reflecting these interactions.

Hodder and Mol (2016) investigated the potential of integrating methods from network analysis with entanglement analysis ( $c f$. Hodder 2012) to investigate what they term 'chainworks' or network paths understood as operational chains. They succeed in several ways by using network concepts like ego networks and path dependencies. Van Oyen $(2015,2016)$ draws on both formal network analysis and wider relational thought, suggesting that researchers not only find relations but also characterize the way they are ordered into what she terms relational constellations. These describe historical trajectories of practices surrounding the production and usage of objects, using terra sigilata pottery as a case study.

There are many other studies of relevance to this topic, such as the use of concepts such as communities of practice (Mills 2016) and collective action (Peeples 2018). Studies integrating qualitative methods of historical analysis have also been integrated with formal network methods (e.g. Düring 2016; Isaksen 2007; Munson and Macri 2009; Sindbæk 2007, 2013; Peeples and Mills 2018). In this paper, I draw on a qualitative framework that has not seen much utilization in archaeological network analysis, namely assemblage theory (but see Kosiba 2019). I have chosen assemblage theory as it has a vocabulary that is eminently suitable to conceptualizing networks of highly contextualized and dynamic relations.

\section{Networks Versus Assemblages}

Manuel Delanda's assemblage theory has gained considerable traction in archaeology, and I will not repeat the many insightful recent works on its archaeological application (see Thomas 2015 and Hamilakis and Jones 2017 for recent overviews). Instead, I will focus on certain concepts regarding relations. Assemblage theory addresses what Delanda refers to as micro-reductive and macro-reductive approaches. Microreductionism assumes that a whole can be reduced to the sum of its parts and that all agency is ultimately attributable to the individuated agents in a social system, while macro-reductionism attributes agency primarily to systems. To overcome these, Delandan assemblages interact and nest together in sets of interactions (DeLanda 2016, p. 82). These assemblages, nested across various scales, exhibit both ascending and descending causal relations, so that the "properties of a whole are produced by the ongoing interactions between its parts, while the whole, once it is stabilized, reacts back to its parts' (DeLanda 2016, p. 83). The term for these interactions is emergent properties.

Delanda (2016, p. 1) defines an assemblage as a whole made up of heterogeneous parts. In other words, assemblages are temporary phenomena composed of entities and their relations, often used to describe social entities. Assemblages are scalable entities 
that can join to form larger assemblages, and their internal consistency can be described using a pair of distinctions. The first is the distinction between relations of interiority and exteriority, which is contingent on the character of the assemblage. For instance, an archaeological institution and its members might have relations of interiority describing the relations between component parts of any one archaeologist and relations of exteriority to describe the relations between the archaeologists, whereas a network of archaeological institutions would treat all of those as interior relations, and the links between institutions as exterior relations. In other words, an interior relation in one assemblage may be treated as an exterior relation in another.

The second distinction is that of territorialization and deterritorialization, a pair of Deleuzo-Guattarian concepts ( $c f$. Deleuze and Guattari 1987). These describe the 'degree to which the components of the assemblage have been subjected to a process of homogenisation, and the extent to which its defining boundaries have been delineated and made impermeable' (DeLanda 2016, p. 3). In other words, territorialization is not (necessarily) a spatial process, but the degree to which an assemblage is ontologically cohesive.

Let us explore the implications of treating archaeological networks as assemblages. ${ }^{3}$ Assemblages influence each other, nest and entwine in top-down and bottom-up causal relations. The implications for an assemblage network (AN) are threefold. Firstly, ANs need the capacity to be influenced by other networks that are related to it spatially or topologically. Secondly, the links between nodes in a network need to, like nodes, be able to exert their own agency over other links and nodes. Finally, ANs need the capacity to nest with each other, creating larger wholes. This last implication goes some way to address interaction at the sub-nodal level as discussed by Strathern (1996) and Knappett (forthcoming, see above) as any node in a network is almost by definition also a nested network in a larger whole, with relations of interiority articulating intraactions, and relations of exteriority articulating interactions.

Of course, we must not forget that network analysis refers primarily to a set of quantitative methods. These methods necessarily simplify data into categorical attributes in order so that a method can be applied consistently to every node and edge. This is one of the strengths of network analysis. While ontologies like Delanda's assemblage theory and Ingold's meshwork linaeology offer a more nuanced picture of social interactions, they offer nothing that could be called a formal methodology for analyzing meshworks or assemblages consistently. These are qualitative approaches, not quantitative ones. But is there a middle ground between formal network analysis and assemblage theory?

To begin with, I want to stress that it is established practice to think of archaeological networks as unbounded and multi-scalar entities, much akin to Delandan assemblages (Collar et al. 2015). There are no immutable networks; only relations that can be brought together to form networks depending on the scale and scope of analysis. But I argue that mapping this middle ground calls for an expressive terminology for describing what a relation in a network implies. I have chosen to use the CIDOC-CRM ontology for this purpose, both for its rich list of classification and its growing influence in archaeoinformatics (e.g. Dörr et al. 2004; Binding et al. 2008, Niccolucci and Richards 2013).

\footnotetext{
$\overline{{ }^{3} \text { Here called assemblage networks. }}$
} 


\section{Documenting the Conditions of Emergence in Archaeological Networks}

Sindbæk (2013) suggests that the use of methods and models developed outside archaeology (social network methods in particular) risks creating poorly supported assumptions about past interactions, concealed by black boxes of generalizing tools and models. As a remediation, he argues for the importance of contextual network synthesis, which he defines as the careful analysis of any relevant data source to provide the network with footnotes of contextual interpretation. I echo that sentiment, but it is important that any such footnotes be an integral part of the primary source itself - the network. To accomplish that, a network model must be able to express the substantive character of edges and nodes, and any nuance that may impact how network interactions proceed. I have chosen to use the CIDOC-CRM ontology for this purpose (see Dörr et al. 2004; Binding et al. 2008; Niccolucci and Richards 2013) as Ísleif, the dataset presented here, is part of the Ariadne infrastructure (Meghini et al. 2017), which has adopted the ontology as a means to connect datasets across Europe.

An ontology in information science is a set of concepts describing the semantics of a data structure. Ontologies are generally used to connect data infrastructures through shared concepts, but they can also be used to describe individual datasets. An ontology does not contain any additional information about a database per se but is a way to structure and classify its contents. An ontology for an archaeological site register might, for instance, group features interpreted as byres, stables and sheep houses together as animal enclosures; an ontology connecting site registers might seek to connect the way in which different national site registers describe animal enclosures through a set of shared concepts.

Discussions of ontologies are still uncommon in the literature on archaeological networks (see, for instance Isaksen 2013; Isaksen et al. 2014; Cardinal 2019); neither is there any discussion of network analysis in recent literature on ontologies in archaeology (e.g. Niccolucci et al. 2015). In other words, there are few archaeological network ontologies to draw on currently. ${ }^{4}$ My choice of CIDOC-CRM is not due to precedent, but potential. The CRM has a rich list of classifications, a growing influence in archaeoinformatics and its user base has shown a commitment to developing extensions to the core ontology to model specific domains of archaeological data.

CIDOC-CRM stands for The International Council of Museums' International Committee for Documentation's Conceptual Reference Model, a rather unwieldy name best left as an acronym. Its primary role is 'to enable information exchange and integration between heterogeneous sources of cultural heritage information' (Crofts et al. 2011, p. 9). It does so by explicitly describing the underlying semantics of database schemata and document structures which enables connectivity across datasets to be defined and mapped. These descriptions draw on a large vocabulary of the socalled classes and properties. A class resembles a node and is defined as one or more items sharing common traits used as criteria for defining a class. These traits are called the intensions of the class (Crofts et al. 2011, p. 9). Properties, much like links, define

\footnotetext{
${ }^{4}$ The only current one perhaps being Pelagios'use of the Open Annotation Ontology, although the author may have overlooked others. In any case, I hope this brief text encourages more discussion and use of ontologies in archaeological network studies.
} 
specific relationships between classes. The class/property distinction makes CIDOC a very suitable ontology for network modelling, as it directly reflects the network ontology of nodes/edges.

Recently, extensions have been developed for CIDOC-CRM, aimed at expanding its capability to handle a variety of knowledge domains. These include CRMarchaeo (Hiebel et al. 2014), providing a semantic map for excavation data; CRMgeo for spatiotemporal data (Hiebel et al. 2016); CRMsci for scientific observations (Dörr et al. 2014) and CRMepi for epigraphs (Felicetti et al. in press). As the ontology has grown, it has built capabilities to describe complex spatiotemporal events such as the fight between the HMS Victory and the Redoubtable at the battle of Trafalgar (Hiebel et al. 2016).

The act of emplacing a cultural object shows the way in which these classes and properties are applied using the reference model (Fig. 1; Dörr et al. 2014):

The graph above shows the means by which CIDOC-CRM maps the description of an object emplacement. Properties of the place are indicated through place appellations like coordinates, place name and address, its recursive relationship to the place itself (defined by its own assemblage of classes and properties) and the agency involved in the moving the physical entity to the place or in its emplaced production. The process aims to externalize any implicit knowledge embedded in archaeological data stores and structure information in clear subject-predicate-object statements that, when linked together, provide a rich semantic context for every strand of data. Similar graphs exist for articulating temporality, ownership, agency and so on. As it is, well over 100 different classes and properties ${ }^{5}$ allow for a richly expressive articulation of database semantics.

CIDOC-CRM makes a distinction between two types of temporally contingent entities. Those that persist through time are termed endurants. By contrast, entities that are tied up with definable, temporally bounded events are called perjurants. This is of course dependent on the temporal scale of analysis. The Snæfellsjökull glacier in Iceland can be seen as an endurant setting for social interaction at one temporal scale and a perjurant entity at another. The distinction between endurant and perjurant networks allows for modelling persistent entities, such as social infrastructures and architectural features, separately from events that may involve those endurant entities at a given period in time. As I will demonstrate below, this enables the documentation of temporally contingent changes to network structure as events unfold (i.e. the creation of perjurant networks) without the need to alter endurant network structure.

Networks modelling complex social dynamics may have relations expressing multiple different kinds of connectivity which are likely to lead to different emergent properties. CIDOC-CRM offers a set of attributes for network relations which can be used to characterize links between nodes in a network and from that develop rules for how new properties might emerge from specific network interactions. Whereas a formal, SNA-type approach to network might be called network quantification, where the strengths of ties can be weighed and tie strengths quantified based on measures such as centrality and transitivity, a CIDOC-CRM approach might be called network characterization as this approach is more concerned with understanding what it means when two nodes are connected in a network. This network characterization should

\footnotetext{
${ }^{5}$ Not counting extensions.
} 


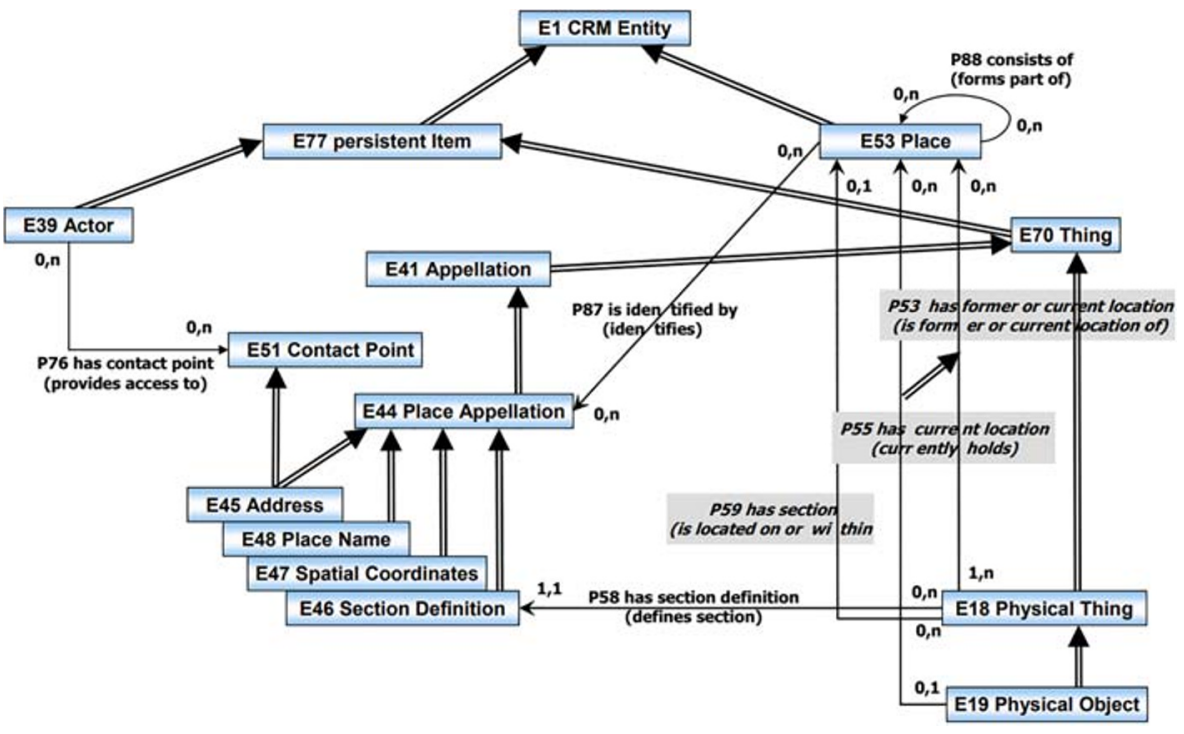

Fig. 1 Emplacement in CIDOC-CRM

precede formal analysis since its objective is to explore how contextual information from related historical and archaeological sources may suggest changes to network structure as relations are acted on, leading to alternative scenarios that can be analyzed formally.

Mapping to the CIDOC-CRM is anything but straightforward. The large number of classes and properties is a strength as well as a weakness, as it is unlikely that any two mappings of similar networks would result in identical mappings. This exploratory case study is far from being a handbook for standardized CIDOC-CRM mapping of networks, but that may become an attainable goal if the archaeological network community adopts CIDOC-CRM — or a similarly expressive ontology — as a common denominator. For now, the brief case studies presented here show CIDOC-CRM's potential.

\section{Jarðabók Árna Magnússonar \& Páls Vídalín: Surveying an Early Eighteenth Century Society}

The case studies presented below are derived from my work using historical documentation to contextualize surveyed archaeological sites in Iceland's largest site register Ísleif (Friðriksson and Vésteinsson 1998). This aspect of Ísleif, Storied lines, ${ }^{6}$ contains some 5000 georeferenced historical documents organized at the farm level. As Ísleif is also organized at the farm level, any site surveyed in Iceland is grouped according to its location within either one of the historically stable, 4000 lögbýli farms, or in open rangelands or commons (see Pálsson 2018 for a detailed description). These historical documents contain many instances of relations between farmsteads, for instance

\footnotetext{
${ }^{6}$ Jardabok.com
} 
resource access rights between farms and shared grazing rights of commons. As it is very difficult to gather diagnostic information about site usage and site relation by topographic survey, Ísleif has proven insightful in understanding how these sites may have been used in the eighteenth century and earlier (e.g. Júlíusson et al. 2019; Pálsson 2019).

Using historical records to contextualize links in archaeological records is becoming more common (see Mills 2017 and Peeples 2019 for recent overviews). Iceland is eminently suitable for this. Iceland has a handful of historical records covering most of the country that describes farm-to-farm interactions, none more detailed than the early eighteenth century Icelandic land census Jarðabók Árna Magnússonar og Páls Vídalín (hereafter JÁM), which has been digitized and imported in its entirety into Storied Lines. The reason why JÁM is so highly detailed might be due to two factors. Firstly, it was compiled by two prolific scholars whose academic impact went well beyond the compilation of JÁM. Secondly, the target audience was an outsider - the Danish king and court - and for that reason, information that would have perhaps been considered common knowledge to an Icelandic audience were nonetheless included in the book. In other words, implicit understandings of how Icelandic agricultural society operated are made explicit in JÁM.

CIDOC-CRM is connected to Ísleif through its PostgreSQL schema. Fields and their relations are mapped to classes and properties through a subject-predicate-object syntax known as RDF triples. Any relation in Storied Lines is also directly given a CIDOC-CRM property. An ownership relation is 'P75: Possesses'; for instance, a claim that one farm had on another is classified as 'P105: has rights on'.

The networks modelled from JÁM are relatively simple, unimodal networks modelling ownership, rental payment, resource access, community structure and so on. But the census descriptions clearly show that these networks exert significant influence on each other, which makes formal analysis of any one network in isolation problematic. Instead, it is better to think of them as a multimodal network of related networks with variable amounts of information provided for any edge between nodes. The following case studies illustrate the divergence between the initial network modelling and the historically documented ways in which the relations were enacted in the past, and CIDOC-CRM's role in producing contextual network syntheses.

\section{Case Study 1: the Knotted Line}

The farm unit played an important part in Icelandic society and administration for most of its history (Karlsson 2000). There were roughly 4000 so-called lögbýli, or main farms, in the country at the beginning of the eighteenth century. All of these were surveyed, but the records for the four easternmost counties were lost in 1728, leaving extant descriptions for approximately 3500 farms. The JÁM census not only lists the owner of every main farm in Iceland but also where they were based, how much rent was paid and in what products and, in some cases, the way in which rent was paid. Rental payment, at a time when long-distance communication took days or weeks, relied on pre-arrangements between the tenant and owner.

Iceland was controlled by the kingdom of Denmark when JÁM was compiled. The crown did not deal directly with its tenants, using instead a network of royal officials 
called umboðsmenn (e.g. ombudsmen), who administered a group of properties on the crown's behalf. One of these, Sigurður Björnsson, oversaw several farmsteads clustered in Hrútafjörður, northern Iceland. He is, however, based a considerable distance away from the farms he administers. The economy of eighteenth century Iceland was still based on the exchanges of material goods; payment of rent by minted coin was rare, and so the payment involved material movement in one form or another. Live sheep were commonly used for payment, and the act of moving this live fee was invariably the responsibility of the tenant. Jarðabók offers an insightful look into how these material exchanges took place. The description of rental payments for the farm Mýrar, for example, reads as follows (Magnússon and Vídalín 1913-1943, VIII, p. 24, translation by author):

Rent 120 ells. Paid during the spring to Stafholt, or sometimes to Alpingi. For the first few years (of Sigurður Björnsson's tenure) it was occasionally paid with livestock in the autumn to Hvítárvellir, where Sigurður lived at the time. ... Proceeds from rented livestock paid in butter to Stafholt or to Hvammur in Norðurárdalur, or to a location within the county specified by Sigurður.

This material exchange involves not just node $\mathrm{A}$ and node $\mathrm{B}$, but multiple interstitial nodes. This mode of rental payment is fluid and its circumstances change during Sigurður's tenure, and one would also imagine succeeding royal officials might arrange the payment differently. Walking this single line shows its dynamism, its roving qualities and the journeys it initiates, both for the tenant and his or her animals as well as for the proprietor.

This example serves as a reminder that every line in the network indicates a negotiated exchange of some manner between people and their things and that these interactions rarely proceed along straight lines. These pushes and pulls of agency, in a sense, are how networks 'maintain their good shape' ( $c f$. DeLanda 2016, p. 30), but this shape is a knotted, tangled one (Fig. 2).

\section{b Saurbær}

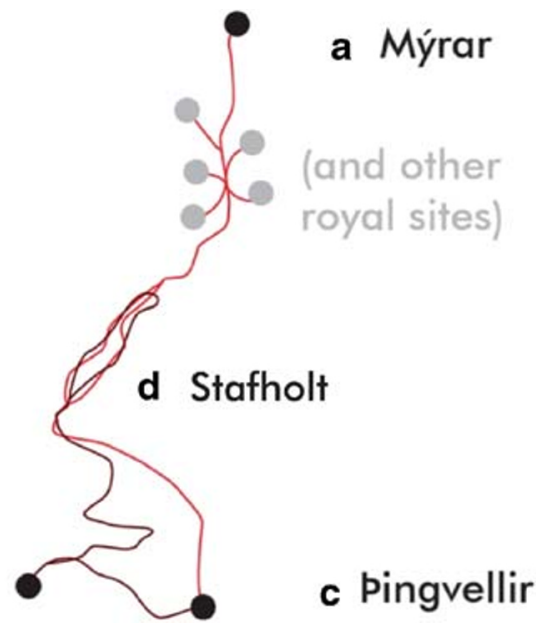

Fig. 2 A spatial abstraction of the journeys taken by tenants delivering rent to Sigurður Björnsson 
Reading any one line in isolation is problematic. In the above example, Sigurður Björnsson most likely requested the same arrangement of all sixteen of the northern tenants he oversaw for the crown, and got around the difficulty in communications by requesting that every tenant leave sheep at either Norðurárdalur, Stafholt or Alpingi, at which point he presumably sent an agent to collect sheep from every tenant in one journey. Here, an emergent property arises from what one could call the parallelism of a particular array of lines or the clustering of a particular set of nodes.

Let us apply the CIDOC-CRM to this example. To begin with, there are multiple sets of interactions that can all be modelled as distinct networks. The first is the Danish empire, which at the time included Greenland, the Faeroe Islands, Iceland, Norway and overseas colonies in the Caribbean, Africa and Asia. I will not explore what implications this had for rent collection in northern Iceland, except to say that it played a small role in a much larger network of material extraction and import to Denmark. Certain elements in the dynamic between the crown and its tenants likely remained constant through time. The crown had possessed the farms in Hrútafjörour since the reformation, some 250 years earlier, and rental payments were a constant fixture. The property network, as is persist through time, is an example of an endurant network. This is the infrastructure, or the space of possibility in Delandan (2016, p. 166), in which every interaction between the crown, its emissaries and its tenants can be articulated. Within this space, multiple events take place that could be modelled as networks. These perjurant networks include the annual rental payment described above. Figure 3 shows the above arrangement modelled as two separate networks, using CIDOC-CRM classifications:

The initial bundle of lines has been re-articulated as a series of nested networks in Fig. 4. The endurant property network has been cut, and Sigurður Björnsson's farm Saurbær added as an interstitial node, connected to the tenant farms using the CIDOCCRM property P50 (is current keeper of). It is complemented by a perjurant network showing the different possible ways in which rent on Mýrar was paid. Finally, a third network shows the physical moving of sheep as a spatial ontology. This exercise in articulating the relational character of the initial network has enabled a disentangling of sorts. We remain aware of the knotted properties of the lines between Sigurður Björnsson and the tenants he oversees. The CIDOC-CRM allows us to peer inside those knots and to better map their complexities.

\section{Case Study 2: the Articulated Line}

No turf cutting on the farm. The tenant travels to Hamar every year by the grace of the bishop's ombudsman, and for this the tenant should pay 20 ells. This turf needs to be transported by land and sea, which takes no less than a whole week and requires horses to move to and from a ship.

The farm Hraun í Fljótum (Magnússon and Vídalín 1913-1943, IX, p. 339, see description above) does not have adequate turf, a vital building resource, and must collect turf from another farm. It does not trade with any of its neighbours, however. Instead, occupants travel south to Hamar, which according to the text is an arduous 


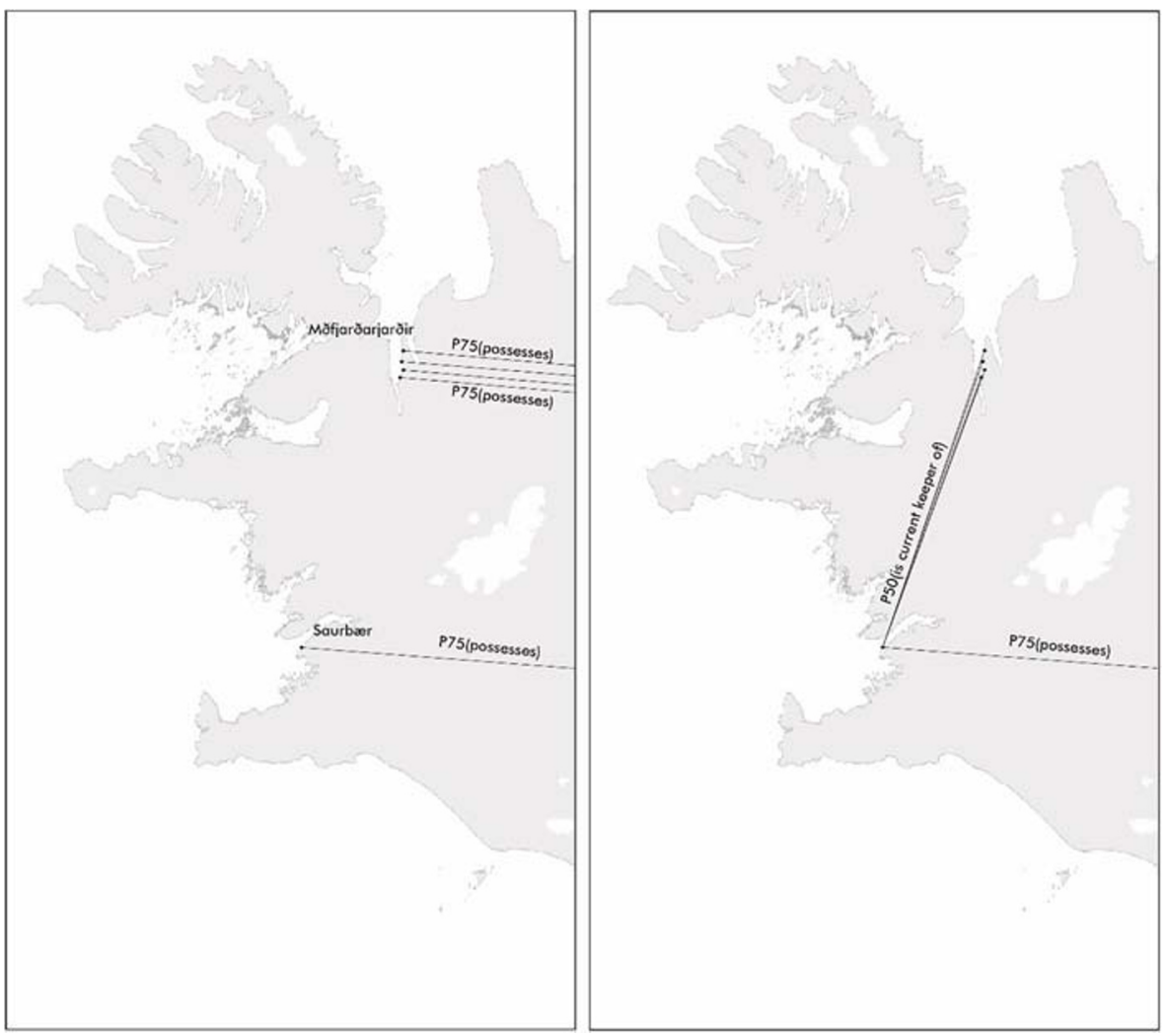

Fig. 3 An example of cutting. The left map shows the royal properties discussed in the case study, with relations defined as P75 (possesses). On the right map, the direct link is cut, and Sigurður Björnsson's farm Saurbær added as an interstitial node, connected to the tenant farms using the property P50 (is current keeper of). Note that the Danish crown owned many more properties in Iceland at the time, not shown for the sake of simplicity

journey that takes over a week every year. The reason for the source of turf stems from the fact that both farms have the same owner, the bishopric at Hólar. It is likely that Hamrar was the closest farm owned by the bishop that had an abundance of turf. Whether or not that was the case, the broader point is that this particular resource exchange arrangement did not arise from a logical interaction between neighbours, but from the decision-making of a regional power. This decision most likely benefited the entire assemblage of properties under the bishopric, even if it led to a particularly cumbersome arrangement for the tenants at Hraun. In other words, the shared ownership of both farms causes an interaction that is more triangular than linear (see Fig. 5). Indeed, mapping the terrestrial resource claims of Hólar's tenants in the region shows that the interactions are exclusively between remote tenants and not the many nearby farmsteads not owned by the bishopric.

This is an example of network triads (see Hage \& Harary 1981, 1996). In other words, the dyadic relations between Hólar and its tenants lead to triadic relations among the tenants. With CIDOC-CRM, it is possible to articulate this transitivity and to begin building heuristic guidelines for how certain dyadic relations lead to 


\section{Miðfjarðarjarðir (royal sites administered by Sigurður Bïörnsson)}
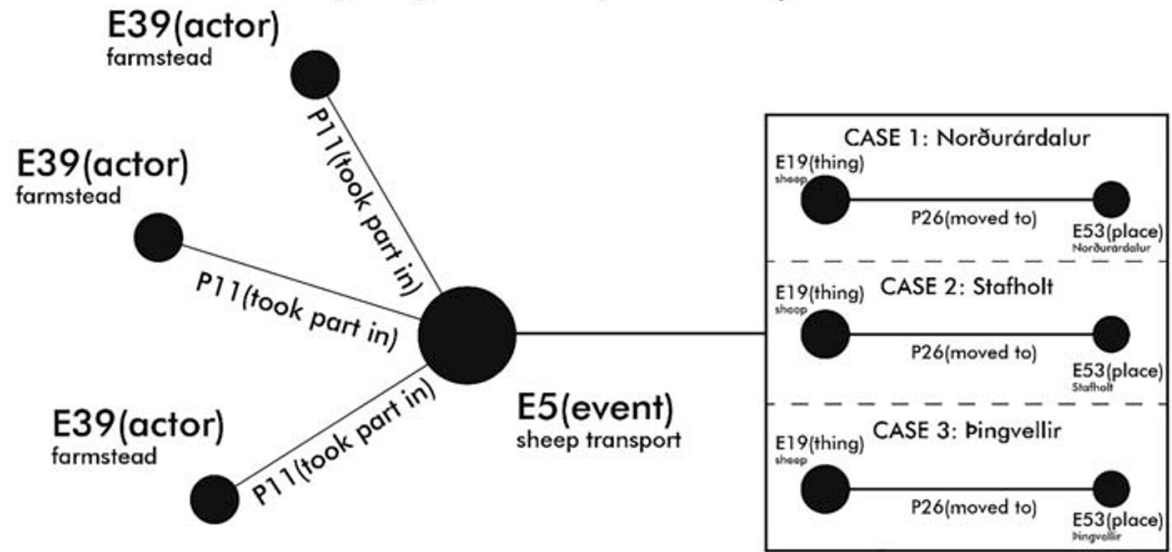

\section{Sheep transport} as a perjurant network

Fig. 4 Conceptualizing rental payment as a perjurant network involving an initial topology focused on the event of sheep transport and a series of nested options showing the movement of sheep from the tenants to one of three options available to the tenant farmers

certain transitive emergent properties. Figure 6 shows these relations, mapped to the CIDOC-CRM.

Let us define one transitive of a property network as the influence an owner has on tenantto-tenant interactions. We can then state that property networks, characterized using CIDOCCRM's property P75 (possesses), are likely to exhibit a set of transitive characteristics commonly found in property networks. Skálholt, the bishopric in the south, often had its tenants deliver rent to the nearby sheep folds. These sheep folds were gathering places for grazing livestock brought back from the uplands after summer grazing (Aldred 2012; Sigurjónsson 1948), but as stable infrastructural nodes in the landscape, they often became mobilized for other uses, such as market exchanges (Ólafsson and Pálsson 1974, p. 105), and in the case of Skálholt, for rent collection. This articulation cuts the modelled network and adds an extra joint to the lines between tenant and owner.

The above figure shows lines generated between Skálholt and its tenants in Árnessýsla and Rangárvallasýsla, using the relational database management system PostgreSQL with its spatial extension, PostGIS. I have chosen to use the centroid of herding communities as a node proxy for the sheep fold over the precise locations of the folds so that the method can more generally be applied using computational algorithms. To mimic the nested networks above, the algorithm generating the linework uses nested conditional functions to add joints to the relations between Skálholt and its tenants, but not between other tenants and owners in the area (Fig. 7).

This method of cutting can be extended to generate a perjurant rent collecting network from the endurant property network, with a function specifying conditional 


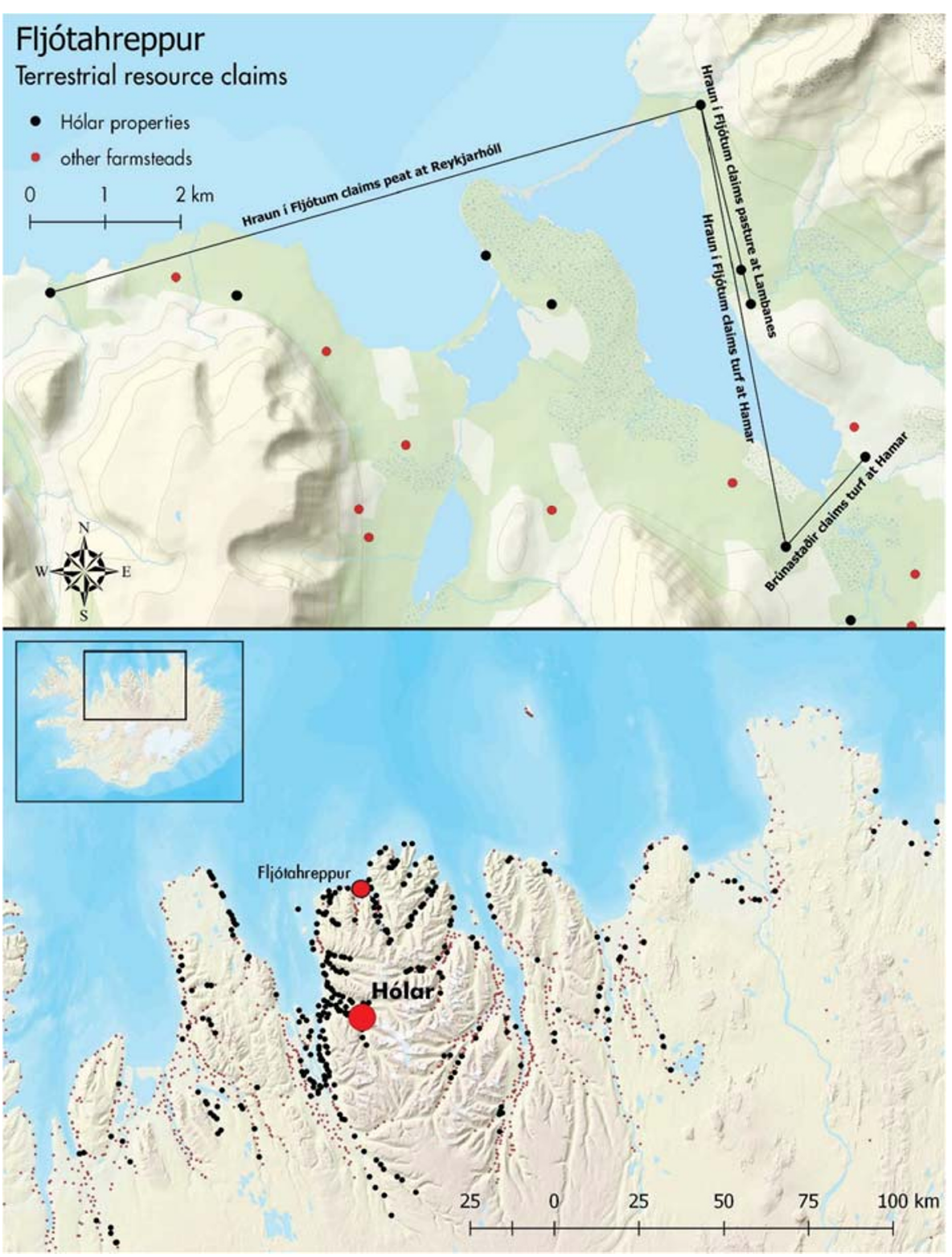

Fig. 5 Episcopal influence on Hólar tenant farmers in Fljótahreppur

cases tailored to any known proprietor which reflect our best understanding of how they interacted with their tenants (Fig. 8).

\section{Conclusions: Lived Lines}

Now that CIDOC-CRM, assemblage theory and a number of case studies have been presented, I would like to discuss whether the approach used in this paper can facilitate 


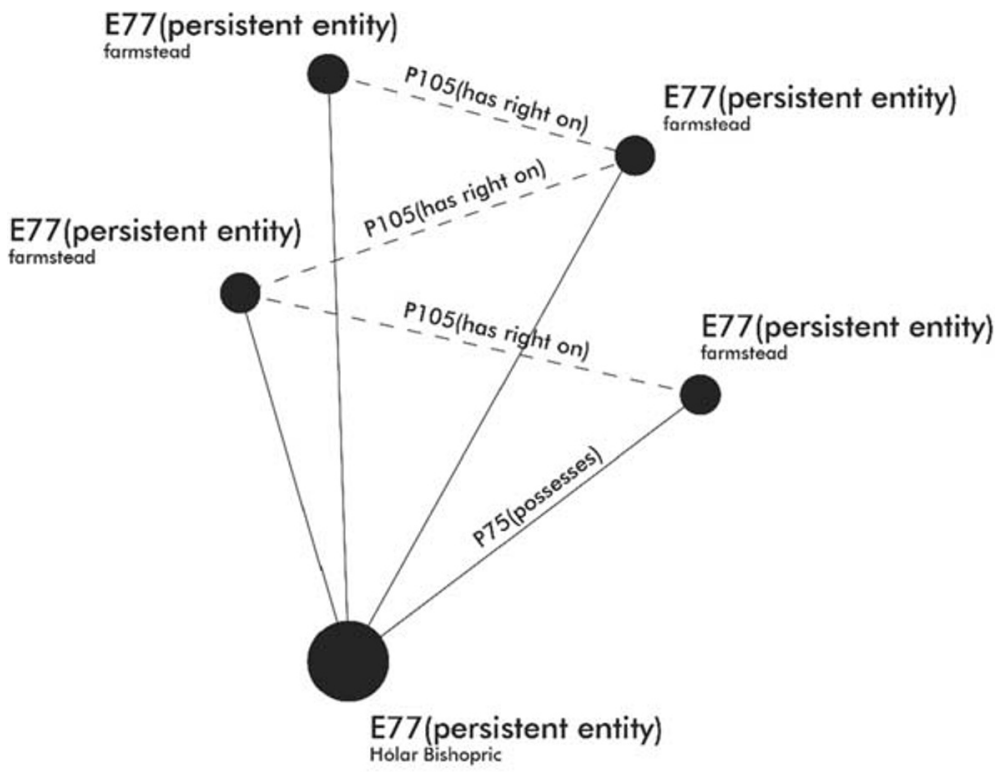

\section{Episcopal transitivity}

Fig. 6 Episcopal transitivity. Secondary relations classed as P105 (has rights on) have been added between some of Hólar's tenants to reflect the high likelihood of tenant-to-tenant resource exchanges, as exemplified by JÁM descriptions in northern Skagafjörður

the inclusion of assemblage theory concepts in network modelling. The distinction between interior and exterior relations is relatively straightforward to model, as any subsample of relations in a network dataset arguably sets that distinction in place. By that token, (de)territorialization can be understood as the character of such a relational subset. In other words, a subset containing only property relations would have a higher territorialization than a subset of multimodal relations.

Neither of these distinctions call for an expressive ontology. CIDOC-CRM's value becomes apparent when considering more complex network characteristics, such as multimodality and influences between unimodal networks. Finally, the distinction between endurant and perjurant temporal entities gives the capacity to model material exchanges that temporarily subvert data-driven network structure or to borrow a distinction from De Certeau (1984), allowing both the strategies of infrastructural stability and the tactics of material exchange to be mapped simultaneously.

As Brughmans (2013, p. 641) points out, network models are not meant to mirror the complexities of society. But that should not preclude attempts to get as close as possible. This paper, and a preceding one based on the same material (Pálsson 2018), presents data on interactions in the past that lend themselves well to being modelled as networks of simple dyadic relations. But when we consider how these relations were actually carried out in the past, we see that these vibrant networks, documented both spatially and historically, regularly show signs of emergent properties. As relations begin to exert their own agency and networks begin influencing one another, the networks are cut, and edges begin to bundle up in knots and entanglements. Yet, these 


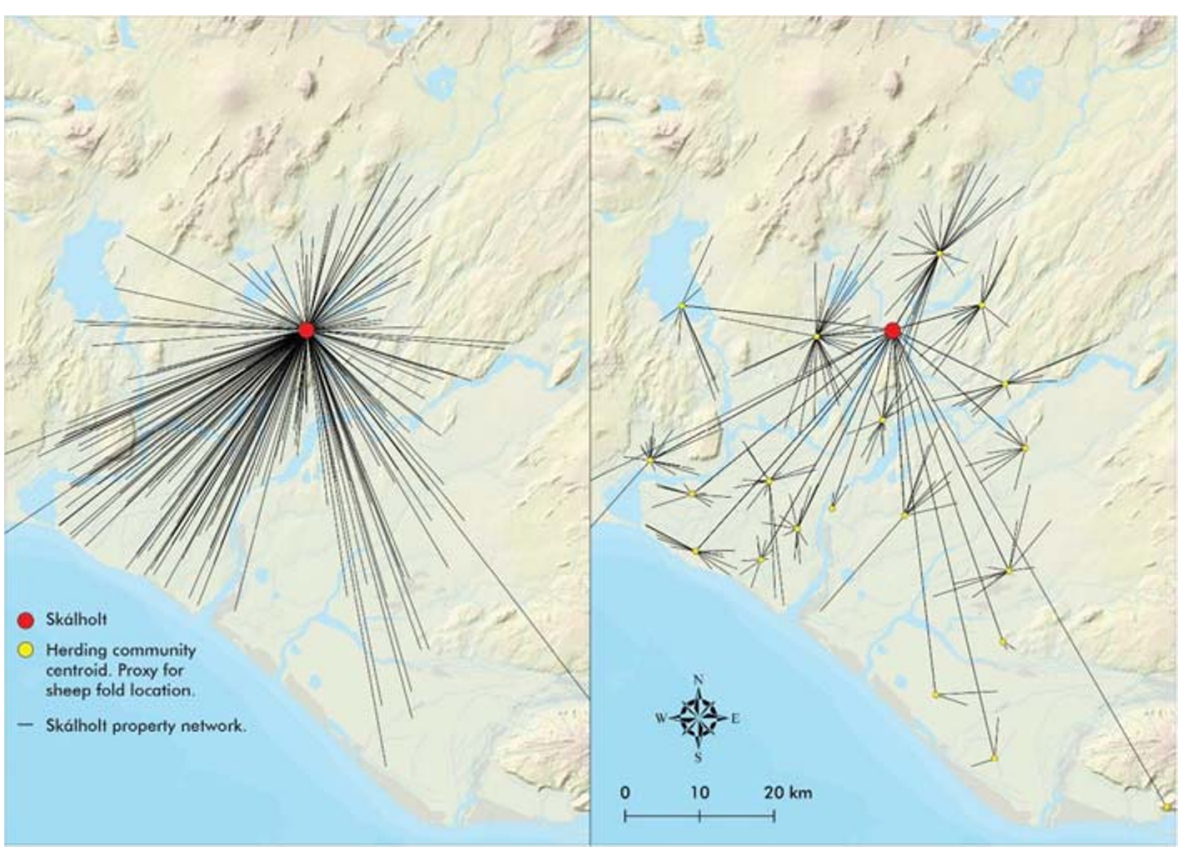

Fig. 7 Cutting the Skálholt property network to simulate a rent-collection network is based on the historically observed practice of using sheep folds as locations for gathering rent

entanglements are patterned. By developing anticipatory heuristics made explicit by the use of a formal computational ontology and SQL-based algorithms, it is possible to suggest cuts across the entire assemblage of networks to reflect how a network might maintain its shape through dynamic events and lived lines.

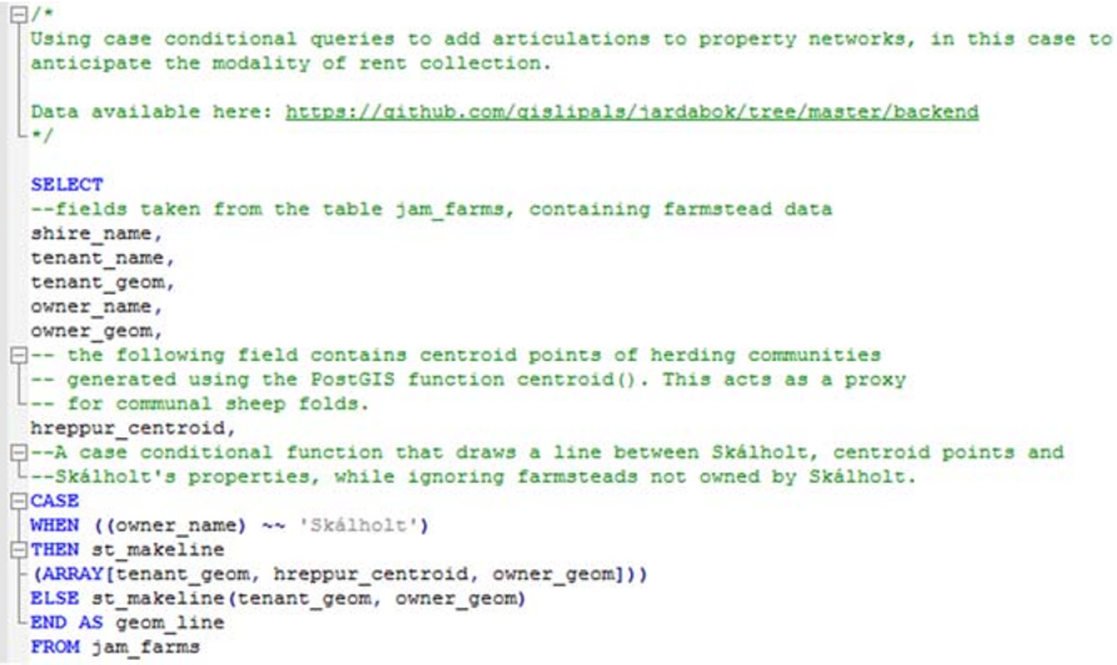

Fig. 8 Using case conditional queries to add articulations to property networks, in this case to anticipate the modality of rent collection 
This article presents a case study using CIDOC-CRM and historical documentation to contextualize relations between sites in Iceland's largest site register, Ísleif. This case study is more concerned with network characterization than network analysis, as the networks presented here are relatively well understood. But that allows for the development of a range of heuristics for how emergent properties might emerge from less understood networks. JÁM's rich descriptions of farmstead interaction are used here as a thickening agent to articulate parts of the network that are described in less detail.

Funding Information Open access funding provided by Umea University.

\section{Compliance with Ethical Standards}

Conflict of Interest The author declares that he has no conflicts of interest.

Open Access This article is licensed under a Creative Commons Attribution 4.0 International License, which permits use, sharing, adaptation, distribution and reproduction in any medium or format, as long as you give appropriate credit to the original author(s) and the source, provide a link to the Creative Commons licence, and indicate if changes were made. The images or other third party material in this article are included in the article's Creative Commons licence, unless indicated otherwise in a credit line to the material. If material is not included in the article's Creative Commons licence and your intended use is not permitted by statutory regulation or exceeds the permitted use, you will need to obtain permission directly from the copyright holder. To view a copy of this licence, visit http://creativecommons.org/licenses/by/4.0/.

\section{References}

Aldred, O. (2012). Mobile communities: The gathering and sorting of sheep in Skútustaðarhreppur, Northeast Iceland. International Journal of Historical Archaeology, 16(3), 488-508.

Amati, V., Shafie, T., \& Brandes, U. (2018). Reconstructing archaeological networks with structural holes. Journal of Archaeological Method and Theory, 25(1), 226-253.

Binding, C., May, K., \& Tudhope, D. (2008). Semantic interoperability in archaeological datasets: Data mapping and extraction via the CIDOC CRM. Paper presented at the International Conference on Theory and Practice of Digital Libraries.

Brughmans, T. (2010). Connecting the dots: Towards archaeological network analysis. Oxford Journal of Archaeology, 29(3), 277-303.

Brughmans, T. (2013). Thinking through networks: A review of formal network methods in archaeology. Journal of Archaeological Method \& Theory, 20, 623-662.

Brughmans, T., \& Peeples, M. (2017). Trends in archaeological network research: A bibliometric analysis. Journal of Historical Network Research, 1(1), 1-24.

Brughmans, T., Collar, A., \& Coward, F. S. (2016). The connected past: Challenges to network studies in archaeology and history. Oxford: Oxford University Press.

Cardinal, J. S. (2019). Sets, graphs, and things we can see: A formal combinatorial ontology for empirical intra-site analysis. Journal of Computer Applications in Archaeology, 2(1).

Collar, A., Coward, F., Brughmans, T., \& Mills, B. J. (2015). Networks in archaeology: Phenomena, abstraction, representation. Journal of Archaeological Method and Theory, 22(1), 1-32.

Crofts, N., Dörr, M., Gill, T., Stead, S., \& Stiff, M. (2011). Definition of the CIDOC conceptual reference model. ICOM/CIDOC Documentation Standards Group. CIDOC CRM Special Interest Group, 5.

De Certeau. (1984). The practice of everyday life. Berkeley: University of California Press.

DeLanda, M. (2006). A new philosophy of society: Assemblage theory and social complexity. New York: Bloomsbury.

DeLanda, M. (2016). Assemblage theory. Edinburgh: Edinburgh University Press.

Deleuze, G., \& Guattari, F. (1987). A thousand plateaus: Capitalism and schizophrenia. Minneapolis: University of Minnesota Press. 
Dörr, M., Schaller, K., \& Theodoridou, M. (2004). Integration of complementary archaeological sources. In F. Niccolucci \& S. Hermon (Eds.), Beyond the artefact - Digital interpretation of the past - Proceedings of CAA2004, Prato, Italy, 2004 (pp. 64-69). Archaeolingua.

Dörr, M., Kritsotaki, A., Rousakis, Y., Hiebel, G., \& Theodoridou, M. (2014). CRMsci: The scientific observation model.

Düring, M. (2016). How reliable are centrality measures for data collected from fragmentary and heterogeneous historical sources? A case study. In T. Brughmans, A. Collar, \& F. Coward (Eds.), The connected past: Challenges to network studies in archaeology and history (pp. 85-101). Oxford: Oxford University Press.

Evans, S., \& Felder, K. (2014). Making the connection: Changing perspectives on social networks. Archaeological Review from Cambridge, 29(1), 9-17.

Felicetti, A., Murano, F., Ronzino, P., \& Niccolucci, F. (in press). CIDOC CRM and Epigraphy: A Hermeneutic Challenge. Extending, Mapping and Focusing the CIDOC-CRM. Proceedings of the CRMEX 2015 Workshop Poznan, Poland, September 17, 2015.

Friðriksson, A., \& Vésteinsson, O. (1998). Ísleif: A database of archaeological sites in Iceland. Archaeologia Islandica, 1, 45-47.

Gell, A. (1999). Strathernograms, or, the semiotics of mixed metaphors. In Hirsch (Ed.), Alfred Gell: The art of anthropology (pp. 29-76). London: Athlone.

Hage, P., \& Harary, F. (1981). Mediation and Power in Melanesia. Oceania, 52(2), 124-135.

Hage, P., \& Harary, F. (1996). Island networks: communication, kinship, and classification structures in Oceania. No. 11. Cambridge: Cambridge University Press.

Hamilakis, Y., \& Jones, A. M. (2017). Archaeology and assemblage. Cambridge Archaeological Journal, 27(1), 77-84.

Hiebel, G., Doerr, M., Hanke, K., \& Masur, A. (2014). How to put archaeological geometric data into context? Representing mining history research with CIDOC CRM and extensions. International Journal of Heritage in the Digital Era, 3(3), 557-577.

Hiebel, G., Doerr, M., \& Eide, Ø. (2017). CRMgeo: A spatiotemporal extension of CIDOC-CRM. International Journal on Digital Libraries, 18, 271-279. https://doi.org/10.1007/s00799-016-0192-4.

Hodder, I. (2012). Entangled: An archaeology of the relationships between humans and things. Chichester: Wiley-Blackwell.

Hodder, I., \& Mol, A. (2016). Network analysis and entanglement. Journal of Archaeological Method and Theory, 23(4), 1066-1094.

Ingold, T. (2011). Being alive: Essays on movement, knowledge and description. Oxon: Routledge.

Ingold, T. (2015). The life of lines. London: Routledge.

Isaksen, L. (2007). Network analysis of transport vectors in Roman Baetica. In J. T. Clark, and E. M. Hagenmeister (Eds.), Digital discovery: Exploring new frontiers in human heritage. Proceedings of the 34th CAA conference, Fargo, 2006, Archaeolingua, Budapest, 64-76.

Isaksen, L. (2008). The application of network analysis to ancient transport geography: A case study of Roman Baetica. Digital Medievalist, 4.

Isaksen, Leif (2013) 'O what a tangled web we weave' - towards a practice that does not deceive. In, Knappett, Carl (ed.) Network analysis in archaeology: New approaches to regional interaction pp. 43-67. Oxford: GB. Oxford University Press.

Isaksen, L., Simon, R., Barker, E. T., \& de Soto Cañamares, P. (2014). Pelagios and the emerging graph of ancient world data. In Proceedings of the 2014 ACM conference on Web science, 197-201.

Júlíusson, Á. D., Lárusdottir, B., Lucas, G., \& Pálsson, G. (2019). Episcopal economics: Property and power in post-reformation Iceland. Scandinavian Journal of History, 1-26.

Karlsson, G. (2000). Iceland's 1100 years: The history of a marginal society. Reykjavík: Mál og Menning.

Knappett, C. (2005). Thinking through material culture: An interdisciplinary perspective. Philadelphia: University of Pennsylvania Press.

Knappett, C. (2011). An archaeology of interaction: Network perspectives on material culture and society. Oxford: Oxford University Press.

Knappett, C. (Ed.). (2013). Network analysis in archaeology: New approaches to regional interaction. Oxford: Oxford University Press.

Knappett, C. (2014). Avant-propos. Les Nouvelles de l'archéologie, 135(1), 5-8.

Knappett, C. (forthcoming). Relational concepts and challenges to network analysis in social archaeology. In L. Donnellan (Ed.), Archaeological networks and social interaction: Network analysis and network concepts in social archaeology. London: Routledge.

Kosiba, S. (2019). New digs: Networks, assemblages, and the dissolution of binary categories in anthropological archaeology. American Anthropologist, 121(2), 447-463. 
Latour, B. (2005). Reassembling the social: An introduction to actor-network-theory. Oxford: Oxford University Press.

Magnússon, Á., \& Vídalín, P. (1913-1943). Jarðabók Árna Magnússonar og Páls Vídalín. Copenhagen: Hið íslenzka fræðafjelag.

Meghini, C., Scopigno, R., Richards, J., Wright, H., Geser, G., Cuy, S., et al. (2017). ARIADNE: A research infrastructure for archaeology. Journal on Computing and Cultural Heritage (JOCCH), 10(3), 18.

Mills, B. J. (2016). Communities of consumption: Cuisines as constellated networks of situated practice. In Knowledge in motion: constellations of learning across time and place (pp. 247-270). Tucson: University of Arizona Press.

Mills, B. J. (2017). Social network analysis in archaeology. Annual Review of Anthropology, 46, 379-397.

Mills, B. J., Roberts Jr., J. M., Clark, J. J., Haas Jr., W. R., Huntley, D., Peeples, M. A., et al. (2013). The dynamics of social networks in the Late Prehispanic US southwest. In C. Knappett (Ed.), Network analysis in archaeology: New approaches to regional interaction (pp. 181-202). Oxford: Oxford University Press.

Munson, J. L., \& Macri, M. J. (2009). Sociopolitical network interactions: A case study of the classic Maya. Journal of Anthropological Archaeology, 28(4), 424-438.

Niccolucci, F., \& Richards, J. D. (2013). ARIADNE: Advanced research infrastructures for archaeological dataset networking in Europe. International Journal of Humanities and Arts Computing, 7(1-2), 70-88.

Niccolucci, F., Hermon, S., \& Doerr, M. (2015). The formal logical foundations of archaeological ontologies. In J. Barcelo \& I. Bogdanovic (Eds.), Mathematics and archaeology (pp. 86-99). Boca Raton: CRC Press.

Ólafsson, E., \& Pálsson, B. (1974). Ferðabók Eggerts Ólafssonar og Bjarna Pálssonar um Ferðir Peirra á Íslandi Árin 1752-1757. Eggert Ólafsson Samdi: Steindór Steindórsson frá Hlöðum Íslenskaði: Örn og Örlygur.

Pálsson, G. (2018). Storied lines: Network perspectives on land use in early modern Iceland. Norwegian Archaeological Review, 51, 112-141.

Pálsson, G. (2019). Domination, subsistence, and interdependence: Tracing resource claim networks across Iceland's post-reformation landscape. Human Ecology, 47, 619-636.

Peeples, M. (2018). Connected communities: Networks, identity, and social change in the ancient cibola world. Tucson: University of Arizona Press.

Peeples, M. A. (2019). Finding a place for networks in archaeology. Journal of Archaeological Research, 1-49.

Peeples, M. A., \& Mills, B. J. (2018). Frontiers of marginality and mediation in the U.S. southwest: A social networks perspective. In K. Harry \& S. Herr (Eds.), Life beyond the boundaries: Constructing identity in edge regions of the north American southwest (pp. 25-56). Boulder: University Press of Colorado.

Sigurjónsson, B. (1948). Göngur og Réttir. Akureyri: Norðri.

Sindbæk, S. M. (2007). The small world of the Vikings: Networks in early medieval communication and exchange. Norwegian Archaeological Review, 40, 59-74.

Sindbæk, S. M. (2013). Broken links and black boxes: Material affiliations and contextual network synthesis in the Viking world. In C. Knappett (Ed.), Network analysis in archaeology: New approaches to regional interaction (pp. 71-94). Oxford: Oxford University Press.

Strathern, M. (1990). The gender of the gift: Problems with women and problems with society in Melanesia. Berkeley: University of California Press.

Strathern, M. (1996). Cutting the network. Journal of the Royal Anthropological Institute, 3, 517-535.

Thomas, J. (2015). The future of archaeological theory. Antiquity, 89(348), 1287-1296.

Van Oyen, A. (2015). Actor-network theory's take on archaeological types: Becoming, material agency and historical explanation. Cambridge Archaeological Journal, 25(1), 63-78.

Van Oyen, A. (2016). Historicising material agency: From relations to relational constellations. Journal of Archaeological Method and Theory, 23(1), 354-378.

Publisher's Note Springer Nature remains neutral with regard to jurisdictional claims in published maps and institutional affiliations.

\section{Affiliations}

\section{Gísli Pálsson ${ }^{1}$}

1 Department of Historical and Religious Studies, Umea University, Umea, Sweden 